\title{
Scientific Notes
}

\section{In vitro propagation of sacha inchi through organogenesis}

\author{
Reynaldo Solis(1), Danter Cachique(1), Juan Carlos Guerrero-Abad(2), \\ María Emilia Ruiz Sánchez ${ }^{(2)}$ and Lourdes Tapia y Figueroa( ${ }^{(3)}$
}

\begin{abstract}
(1)Instituto de Investigaciones de la Amazonía Peruana, San Martín, Jirón Belén Torres de Tello, no 135, Tarapoto, San Martín, Peru. E-mail: rsolis@iiap.org.pe, dcachique@iiap.org.pe (2)Universidad Nacional de San Martín, Jirón Amorarca, no 315, Tarapoto, San Martín, Peru. E-mail: jc.guerrero.abad@gmail.com, rubimushuk@gmail.com ${ }^{(3)}$ Universidad Nacional Agraria La Molina, Avenida La Molina, s/no, La Molina, Lima, Peru. E-mail: Itapia@lamolina.edu.pe
\end{abstract}

\begin{abstract}
The objective of this work was to evaluate hormonal balance in the phases of the in vitro organogenesis of apical meristems of sacha inchi (Plukenetia volubilis). For the establishment and multiplication phases, Murashige \& Skoog (MS) media, with different concentrations of benzylaminopurine (BAP) and naphthaleneacetic acid (NAA), were used. For rooting, modified MS media was supplemented with different concentrations of NAA and indolebutyric acid. The differentiation of apical meristems was possible with $0.1 \mathrm{mg}$ $\mathrm{L}^{-1} \mathrm{BAP}$ and $0.05 \mathrm{mg} \mathrm{L}^{-1} \mathrm{NAA}$. The best rooting of seedlings is obtained with $0.5 \mathrm{mg} \mathrm{L}^{-1}$ naphthaleneacetic acid and $2.0 \mathrm{mg} \mathrm{L}^{-1}$ indolebutyric acid.
\end{abstract}

Index terms: Plukenetia volubilis, apical meristem, seedling, vegetative propagation.

\section{Propagação in vitro de sacha inchi por meio da organogênese}

Resumo - O objetivo deste trabalho foi avaliar o balanço hormonal em fases da organogênese in vitro de ápices meristemáticos de sacha inchi (Plukenetia volubilis). Para as fases de estabelecimento e multiplicação, foi utilizado o meio de cultivo Murashige \& Skoog (MS) com diferentes concentrações de benzilaminopurina (BAP) e ácido naftalenoacético (ANA). Para o enraizamento, o meio MS modificado foi suplementado com diferentes concentrações de ANA e ácido indolbutírico. A diferenciação dos ápices meristemáticos foi possível com a adição de $0,1 \mathrm{mg} \mathrm{L}^{-1}$ de BAP e $0,05 \mathrm{mg} \mathrm{L}^{-1}$ de ANA. O melhor desempenho do enraizamento de plântulas é obtido com a adição de $0,5 \mathrm{mg} \mathrm{L}^{-1}$ de ácido naftalenoacético e $2,0 \mathrm{mg} \mathrm{L}^{-1}$ de ácido indolbutírico.

Termos para indexação: Plukenetia volubilis, ápices meristemáticos, plântulas, propagação vegetativa.

Sacha inchi (Plukenetia volubilis L.) is a perennial, oleaginous plant of the Euphorbiaceae family, native of the rainforest of the Amazon Region of South America and mostly found from sea level to less than 1,000 $m$ altitude (Bussmann et al., 2013). This species is a new oilseed crop that has been incorporated into the agricultural activity in the Amazon (Cachique et al., 2011) due to the high contents of unsaturated fatty acids in its seeds (Chirinos et al., 2013) and to its potential for pharmaceutical and nutritional uses.

Sacha inchi can be grown in degraded soils, generating positive environmental impacts. However, because it is a cross-pollinated crop, its propagation through seeds generates heterogeneous plants, making the expansion of new planting areas difficult (Cachique, 2006). Therefore, genetic improvement is necessary to make commercial exploitation feasible, especially regarding seed quality (Oliveira et al., 2013).
Since sacha inchi propagation is mainly by seeds and not by asexual pathway, vegetative propagation would be a good tool to support breeding programs, particularly those that use wild relatives of the species (Cachique et al., 2011; Bordignon et al., 2012; Solis et al., 2017). This way, it would be possible to optimize the direct benefits of selected genotypes, with resistance to pests and diseases, high yields, and high oil content. For sacha inchi, vegetative propagation through root cuttings in sub-irrigation propagators has been carried out using $0.2 \%$ indolebutyric acid (IBA) as a hormonal inductor, $8-\mathrm{cm}$ cuttings (base or middle of the plant) with leaf areas of 50 or $100 \mathrm{~cm}^{2}$, and medium-textured sand as substrate (Cachique et al., 2011).

The use of tissue culture is an alternative for the clonal propagation of sacha inchi. It allows the selection of genetic material, handling large volumes of seedlings in small spaces, and maintaining a

Pesq. agropec. bras., Brasília, v.53, n.11, p.1285-1288, Nov. 2018 DOI: $10.1590 / \mathrm{S} 0100-204 X 2018001100012$ 
stock of disease-free plants. Studies have shown that apical segments obtained from seeds germinated in vitro formed shoots by direct organogenesis in the Murashige \& Skoog (MS) media, using $1.0 \mathrm{mg} \mathrm{L}^{-1}$ benzylaminopurine (BAP) and $0.1 \mathrm{mg} \mathrm{L}^{-1}$ IBA (Bordignon et al., 2012). Nodal segments were also rooted in the modified MS media (half concentration of $\mathrm{NH}_{4} \mathrm{NO}_{3}$ and $\mathrm{KNO}_{3}$ ) supplemented with $2.0 \mathrm{mg} \mathrm{L}^{-1}$ naphthaleneacetic acid (NAA) and $1.0 \mathrm{mg} \mathrm{L}^{-1}$ IBA (Millones \& Vásquez, 2008). Field evaluations showed an increase in productivity and no genetic variability in plants propagated through in vitro culture, compared with those propagated by seeds (Viegas Rodrigues et al., 2014).

The objective of this work was to evaluate hormonal balance in the phases of the in vitro organogenesis of apical meristems of sacha inchi.

The apical buds used in the study were obtained from plants germinated in a greenhouse. In a laminar flow chamber, they were disinfected with alcohol $70 \%$ for $60 \mathrm{~s}$ and $\mathrm{NaOCl} 1 \%$ for $10 \mathrm{~min}$, and then rinsed three times with sterile distilled water. With the aid of the SZ2 Olympus stereo microscope (Leco Corporation, Saint Joseph, MI, USA), sterilized tweezers and scalpels, the meristems were extracted from the apical buds and inoculated in the in vitro establishment phase. In all phases (establishment, multiplication, and rooting), glass flasks, each containing $20 \mathrm{~mL}$ culture medium, were used. The explants were incubated under a photoperiod of 16 hours of light and 8 hours of darkness, average temperature of $24^{\circ} \mathrm{C}$, relative humidity of $46 \%$, and light intensity of 2,000 lux.

The aim of the establishment phase was to determine the best concentration of BAP and NAA for the in vitro establishment of apical meristems. The culture media used included MS salts, MS vitamins (Murashige \& Skoog, 1962), $0.4 \mathrm{mg} \mathrm{L}^{-1}$ ascorbic acid, $30 \mathrm{~g} \mathrm{~L}^{-1}$ sucrose, three concentrations of BAP (0.00, 0.05 , and $0.10 \mathrm{mg} \mathrm{L}^{-1}$ ), and three concentrations of NAA $\left(0.00,0.01\right.$, and $\left.0.05 \mathrm{mg} \mathrm{L}^{-1}\right)$. Nine treatments were carried out, with five replicates per treatment and four explants per replicate.

In the multiplication phase, the effect of three concentrations of BAP $\left(0.10,0.25\right.$, and $\left.0.50 \mathrm{mg} \mathrm{L}^{-1}\right)$ and of three concentrations of NAA $(0.00,0.10$, and $\left.0.25 \mathrm{mg} \mathrm{L}^{-1}\right)$ was evaluated, totaling nine treatments, with five replicates per treatment and four explants per replicate. The shoots used were obtained in the establishment phase, and the basal culture media were the same as in the previous phase.

For rooting, the shoots used were obtained in the multiplication phase, and the culture media included modified MS salts (half concentration of $\mathrm{NH}_{4} \mathrm{NO}_{3}$ and $\mathrm{KNO}_{3}$ ) (Millones \& Vásquez, 2008), MS vitamins, two concentrations of NAA ( 0.5 and $\left.2.0 \mathrm{mg} \mathrm{L}^{-1}\right)$, three concentrations of IBA $\left(0.5,1.0\right.$, and $\left.2.0 \mathrm{mg} \mathrm{L}^{-1}\right)$, and $30 \mathrm{~g} \mathrm{~L}^{-1}$ sucrose. In this case, six treatments were performed, with five replicates per treatment and three explants per replicate.

Evaluations in each phase were carried out five weeks after the explants were transferred to the culture media. A completely randomized design was used. The data were subjected to the analysis of variance, and means were compared by Tukey's test, at $5 \%$ probability.

Since the endogenous concentration of auxins is not enough when meristems are used in in vitro propagation, the exogenous addition of this growth regulator is required (Solis L. et al., 2011). The interaction of different concentrations of BAP and NAA influenced the number and height of shoots in the in vitro establishment of apical meristems. Sprouting began 14 days after the apical meristems were transferred to the culture media, and the use of $0.10 \mathrm{mg} \mathrm{L}^{-1}$ BAP and $0.05 \mathrm{mg} \mathrm{L}^{-1}$ NAA allowed obtaining $14.55-\mathrm{mm}$ seedlings with 1.4 shoots. Purkayastha et al. (2010) observed that the use of BAP in the in vitro regeneration of physic nut (Jatropha curcas L.) shoot apices was the most effective, and that $2.5 \mu \mathrm{mol} \mathrm{L}{ }^{-1}$ induced an average of 6.2 shoots per apex. In the present study, the treatment without growth regulators resulted in smaller seedlings; therefore, the exogenous addition of auxins was required for the in vitro establishment of apical meristems of sacha inchi.

The obtained results are indicative that an adequate balance between cytokinins and auxins in the culture media is necessary for the development of seedlings from apical meristems (Solis L. et al., 2011). This balance depends on the growth regulators added to the culture media (Bordignon et al., 2012) and on their endogenous concentration in the explant, which varies according to the species and type of explant (Pedroza-Manrique \& Mican-Gutiérrez, 2006). The increase in the concentration of growth regulators also increased the sprouting percentage of the apical 
segments of sacha inchi (Bordignon et al., 2012). In the present study, higher concentrations of growth regulators induced the sprouting of axillary buds and allowed obtaining larger seedlings with more shoots. Apical meristems, as an initial explant, were also used in other species, such as papaya (Carica papaya L.), with positive results to initiate an in vitro propagation process (Solis L. et al., 2011), as verified in the present work.

The proliferation of axillary buds is possible with the addition of cytokinins to the culture media, in order to break the apical dominance and stimulate bud sprouting in leaf axils (Saucedo et al., 2008). In the multiplication phase, five weeks after the shoots were transferred to the culture media, the best seedling development was observed with the combination of $0.10 \mathrm{mg} \mathrm{L}^{-1}$ BAP and $0.25 \mathrm{mg} \mathrm{L}^{-1}$ NAA (Table 1). Similarly, after nine weeks of in vitro culture, the apical segments of sacha inchi developed shoots by direct organogenesis at the concentrations of 0.5 and $1.0 \mathrm{mg} \mathrm{L}^{-1}$ BAP associated with $0.1 \mathrm{mg} \mathrm{L}^{-1}$ IBA (Bordignon et al., 2012).

The use of BAP positively affected the shoot formation of sacha inchi (Bordignon et al., 2012) and other species of the Euphorbiaceae family, such as Phyllanthus caroliniensis Walter (Catapan et al., 2000). However, high concentrations of BAP suppressed shoot formation of sacha inchi (Bordignon et al., 2012), since, when the concentration of this cytokinin

Table 1. Effects of different concentrations of benzylaminopurine (BAP) and naphthaleneacetic acid (NAA) in the in vitro multiplication of sacha inchi (Plukenetia volubilis) $^{(1)}$.

\begin{tabular}{lcccc}
\hline $\begin{array}{l}\text { BAP } \\
\left(\mathrm{mg} \mathrm{L}^{-1}\right)\end{array}$ & $\begin{array}{c}\text { NAA } \\
\left(\mathrm{mg} \mathrm{L}^{-1}\right)\end{array}$ & $\begin{array}{c}\text { Shoot height } \\
(\mathrm{mm})\end{array}$ & $\begin{array}{c}\text { Number of } \\
\text { shoots }\end{array}$ & $\begin{array}{c}\text { No. of nodal } \\
\text { segments per } \\
\text { shoot }\end{array}$ \\
\hline 0.10 & 0.00 & $15.10 \mathrm{bcd}$ & $1.75 \mathrm{ab}$ & $2.10 \mathrm{ab}$ \\
0.10 & 0.10 & $16 . .40 \mathrm{~b}$ & $1.90 \mathrm{ab}$ & $2.20 \mathrm{ab}$ \\
0.10 & 0.25 & $18.35 \mathrm{a}$ & $2.25 \mathrm{a}$ & $2.35 \mathrm{a}$ \\
0.25 & 0.00 & $15.15 \mathrm{bcd}$ & $2.00 \mathrm{ab}$ & $2.10 \mathrm{ab}$ \\
0.25 & 0.10 & $16.05 \mathrm{~b}$ & $2.10 \mathrm{ab}$ & $2.40 \mathrm{a}$ \\
0.25 & 0.25 & $15.75 \mathrm{bc}$ & $1.95 \mathrm{ab}$ & $2.25 \mathrm{ab}$ \\
0.50 & 0.00 & $14.70 \mathrm{~cd}$ & $1.75 \mathrm{ab}$ & $1.90 \mathrm{~b}$ \\
0.50 & 0.10 & $14.70 \mathrm{~cd}$ & $1.60 \mathrm{~b}$ & $2.12 \mathrm{ab}$ \\
\hline 0.50 & 0.25 & $14.40 \mathrm{~d}$ & $1.85 \mathrm{~b}$ & $2.05 \mathrm{~b}$ \\
\hline
\end{tabular}

(1)Means followed by equal letters, in the columns, do not differ by Tukey's test, at $5 \%$ probability. The shoots used in the multiplication test were obtained in the in vitro establishment. was increased, smaller plants were obtained; the best results were related to the use of $0.10 \mathrm{mg} \mathrm{L}^{-1}$ BAP. Despite the important role of cytokinins, the addition of auxins was necessary to stimulate shoot growth, and the use of $0.25 \mathrm{mg} \mathrm{L}^{-1} \mathrm{NAA}$ allowed obtaining larger seedlings with more shoots (Table 1).

The role of auxins in the induction and growth of roots is well known; therefore, this hormone has been used in the rooting culture media (Millones \& Vásquez, 2008; Bordignon et al., 2012) and in the rooting induction of cuttings in sub-irrigation propagators of sacha inchi (Cachique et al., 2011) and wild relatives (Solis et al., 2017). The treatment containing $0.5 \mathrm{mg} \mathrm{L}^{-1} \mathrm{NAA}$ and $2.0 \mathrm{mg} \mathrm{L}^{-1}$ IBA presented the highest percentage of rooting $(73.33 \%)$ and allowed the development of higher quality seedlings (Table 2). Bordignon et al. (2012) found that the use of $0.5 \mathrm{mg} \mathrm{L}^{-1}$ IBA allows an adequate root development in apical segments. These results contrast with those obtained by Millones \& Vásquez (2008), who reported that NAA is more effective than IBA in the in vitro rooting of sacha inchi. It should be noted that the roots developed in vitro are not fully functional due to the scarcity of absorbent hairs. According to Solis L. et al. (2011), the formation of many large roots will induce the development of new roots and absorbent hairs in ex vitro conditions during the acclimatization process. In the present study, a greater number of large roots was obtained when using $0.5 \mathrm{mg} \mathrm{L}^{-1} \mathrm{NAA}$ and $2.0 \mathrm{mg} \mathrm{L}^{-1}$ IBA (Table 2).

Table 2. Effects of different concentrations of naphthaleneacetic acid (NAA) and indolebutyric acid (IBA) in the in vitro rooting of sacha inchi (Plukenetia volubilis) ${ }^{(1)}$.

\begin{tabular}{lcccc}
\hline $\begin{array}{l}\text { NAA } \\
\left(\mathrm{mg} \mathrm{L}^{-1}\right)\end{array}$ & $\begin{array}{c}\text { IBA } \\
\left(\mathrm{mg} \mathrm{L}^{-1}\right)\end{array}$ & $\begin{array}{c}\text { Rooting } \\
(\%)\end{array}$ & $\begin{array}{c}\text { Number of } \\
\text { roots }\end{array}$ & $\begin{array}{c}\text { Length of } \\
\text { roots }(\mathrm{mm})\end{array}$ \\
\hline 0.5 & 0.5 & $6.67 \mathrm{~b}$ & $1.00 \mathrm{c}$ & $1.80 \mathrm{~d}$ \\
0.5 & 1.0 & $40 \mathrm{ab}$ & $2.50 \mathrm{abc}$ & $8.02 \mathrm{bc}$ \\
0.5 & 2.0 & $73.33 \mathrm{a}$ & $3.37 \mathrm{a}$ & $12.68 \mathrm{a}$ \\
2.0 & 0.5 & $26.67 \mathrm{ab}$ & $1.60 \mathrm{bc}$ & $6.93 \mathrm{c}$ \\
2.0 & 1.0 & $46.67 \mathrm{ab}$ & $2.60 \mathrm{abc}$ & $10.13 \mathrm{abc}$ \\
\hline 2.0 & 2.0 & $60 \mathrm{ab}$ & $2.73 \mathrm{ab}$ & $11.70 \mathrm{ab}$ \\
\hline
\end{tabular}

${ }^{(1)}$ Means followed by equal letters, in the columns, do not differ by Tukey's test, at $5 \%$ of probability. The shoots used in the rooting test were obtained in the multiplication phase. 
In other species of the Euphorbiaceae family, such as $P$. caroliniensis, it is not necessary to use auxins for rooting (Catapan et al., 2000), which showed high percentages in MS culture media without growth regulators.

The best differentiation of apical meristems was achieved with the combination of $0.1 \mathrm{mg} \mathrm{L}^{-1}$ BAP and $0.05 \mathrm{mg} \mathrm{L}^{-1} \mathrm{NAA}$. In the multiplication phase, the seedlings with more shoots and nodes per shoot were obtained with $0.1 \mathrm{mg} \mathrm{L}^{-1} \mathrm{BAP}$ and $0.25 \mathrm{mg} \mathrm{L}^{-1}$ NAA. The highest percentage of rooting (73.33\%) was a result of the association of $0.5 \mathrm{mg} \mathrm{L}^{-1} \mathrm{NAA}$ and $2.0 \mathrm{mg} \mathrm{L}^{-1}$ IBA. Therefore, the use of the in vitro culture technique for the production of sacha inchi seedlings is feasible when apical meristems are used as an initial explant.

\section{References}

BORDIGNON, S.R.; AMBROSANO, G.M.B.; VIEGAS RODRIGUES, P.H. Propagação in vitro de Sacha inchi. Ciência Rural, v.42, p.1168-1172, 2012. DOI: 10.1590/S010384782012005000049.

BUSSMANN, R.; PANIAGUA-ZAMBRANA, N.; TÉLlEZ, C. Plukenetia carolis-vegae (Euphorbiaceae): a new useful species from Northern Peru. Economic Botany, v.67, p.387-392, 2013. DOI: $10.1007 / \mathrm{s} 12231-013-9247-2$.

CACHIQUE, D. Estudio de la biología floral y reproductiva en el cultivo de sacha inchi (Plukenetia Volubilis L.). 2006. 70p. Tesis (Ingeniero agrónomo) - Universidad Nacional de San Martín, Perú.

CACHIQUE, D.; RODRIGUEZ, A.; RUIZ-SOLSOL, H.; VALLEJOS, G.; SOLIS, R. Propagación vegetativa del sacha inchi (Plukenetia volubilis L.) mediante enraizamiento de estacas juveniles en cámaras de subirrigación en la Amazonía Peruana. Folia Amazónica, v.20, p.95-100, 2011. DOI: 10.24841/ fa.v20i1-2.348.

CATAPAN, E.; OTUKI, M.F.; VIANA, A.M. In vitro culture of Phyllanthus caroliniensis (Euphorbiaceae). Plant Cell, Tissue and Organ Culture, v.62, p.195-202, 2000. DOI: 10.1023/A:1006406806839.
CHIRINOS, R.; ZULOETA, G.; PEDRESCHI, R.; MIGNOLET, E.; LARONDELLE, Y.; CAMPOS, D. Sacha inchi (Plukenetia volubilis): a seed source of polyunsaturated fatty acids, tocopherols, phytosterols, phenolic compounds and antioxidant capacity. Food Chemistry, v.141, p.1732-1739, 2013. DOI: 10.1016/j.foodchem.2013.04.078.

MILLONES, C.E.; VÁSQUEZ, E.R. Micropropagación de plantas de sacha inchi (Plukenetia volubilis L.) provenientes de la provincia de Rodríguez de Mendoza, Región Amazonas. Investigaciones Amazonenses, v.2, p.7-11, 2008.

MURASHIGE, T.; SKOOG, F. A revised medium for rapid growth and bioassays with tobacco tissue culture. Physiology Plantarum, v.15, p.473-497, 1962. DOI: 10.1111/j.1399-3054.1962. tb08052.x.

OLIVEIRA, S.A.G.; LOPES, M.T.G.; CHAVES, F.C.M.; MARTINS, C.C.; ALVES, E.U. Estimation of genetic parameters of Plukenetia volubilis L. seed germination. Revista de Ciências Agrárias, v.56, p.49-54, 2013. DOI: 10.4322/rca.2013.080.

PEDROZA-MANRIQUE, J.; MICAN-GUTIÉRREZ, Y. Asymbiotic germination of Odontoglossum gloriosum RCHB.F (Orchidaceae) under in vitro conditions. In Vitro Cellular \& Developmental Biology - Plant, v.42, p.543-547, 2006. DOI: 10.1079/IVP2006793.

PURKAYASTHA, J.; SUGLA, T.; PAUL, A.; SOLLETI, S.K.; MAZUMDAR, P.; BASU, A.; MOHOMMAD, A.; AHMED, Z.; SAHOO, L. Efficient in vitro plant regeneration from shoot apices and gene transfer by particle bombardment in Jatropha curcas. Biologia Plantarum, v.54, p.13-20, 2010. DOI: 10.1007/ s10535-010-0003-5.

SAUCEDO, S.G.; RAMOS, L.E.; REYES, T.X. Efecto de los reguladores de crecimiento para la propagación in vitro de la malanga (Xanthosoma sagittifolium (L) Schott). Ciencia y Tecnología, v.1, p.17-21, 2008. DOI: 10.18779/cyt.v1i1.97.

SOLIS L., R.; OLIVERA S., J.; LA ROSA L., R.S. Propagación in vitro de Carica papaya var. PTM-331 a partir de meristemos apicales. Revista Peruana de Biología, v.18, p.343-347, 2011.

SOLIS, R.; PEZO, M.; DIAZ, G.; ARÉVALO, L.; CACHIQUE, D. Vegetative propagation of Plukenetia polyadenia by cuttings: effects of leaf area and indole-3-butyric acid concentration. Brazilian Journal of Biology, v.77, p.580-584, 2017. DOI: 10.1590/1519-6984.20415.

VIEGAS RODRIGUES, P.H.; BORDIGNON, S.R.; AMBROSANO, G.M.B. Desempenho horticultural de plantas propagadas in vitro de Sacha inchi. Ciência Rural, v.44, p.10501053, 2014. DOI: 10.1590/S0103-84782014000600016.

Received on March 19, 2017 and accepted on January 5, 2018 